\title{
Budgeting Attitudes in Smaller Universities: A Function of the Environment, Environmental Outcomes, and Personal Outcomes
}

\author{
BERNADETTE SCHELL* and DEBRA TARNOPOLSKY†
}

\begin{abstract}
Academic and administrative staff involved in the budget process in four small-medium universities in Ontario responded to a 16-page mail questionnaire on budgeting attitude as it relates to content, context, process, environmental outcomes, and personal factors. The results showed that for this setting, budgetees seem to have positive budget attitudes, high academic satisfaction levels, and high commitment levels. There was some dissatisfaction expressed, however, with many economic facets, including the university budget, the faculty budgets, the university's long-range plans, and the university's external relations. The personal budget history and values as motivators appeared to have less of an effect on budgetary attitude than did the respondent's definition of a budget, the perception of a consultative, fair superior-subordinate leadership style, and the fact that the superior holds the budgetee personally accountable for budget variances within the department. As hypothesized, there was not a significant difference in budget attitude scores between those of an administrative background and those of an academic background. Objectives for administrators in this particular environment are discussed.
\end{abstract}

\section{RÉSUMÉ}

Les membres du personnel administratif et du corps enseignant associés au processus d'organisation budgétaire au sein de quatre petites oy moyennes universités de l'Ontario ont été invités à répondre à un questionnaire de 16 pages qui leur a été envoyé par courrier et portait sur leur comportement en matière de planification budgétaire. Ce comportement était analysé en tenant compte des mesures d'application et du contexte d'élaboration du budget, des diverses méthodes de travail, des effets attendus sur le milieu et de divers facteurs

*Professor, School of Commerce and Administration, Laurentian University

$\dagger$ Comptroller, Laurentian University 
individuels. Les résultats ont montré que, dans les limites de ce cadre, les responsables des budgets avaient une attitude positive, un niveau de satisfaction professionnelle élevé et un niveau de motivation excellent. On a pu percevoir toutefois un certain mécontentement vis-à-vis de plusieurs aspects d'ordre plutôt économique : le budget dont dispose leur université, les fonds alloués aux diverses facultés, la planification à long terme de l'université et les relations que cette dernière entretient avec le monde extérieur. Le parcours professionnel et financier des responsables de budgets est apparu comme un élément de motivation moindre que l'idée que ceux-ci se faisaient d' un budget; en effet, perçoivent-ils une gestion fondée sur la consultation comme une relation juste entre supérieur et subalterne? Pensent-ils que leur supérieur les considèrent comme personnellement responsables des différences de répartition qui pourraient avoir lieu au sein d' un département? Conformément aux hypothèses émises, il n'y a pas vraiment de différence de comportement entre ceux qui ont une formation en administration et ceux qui ont une formation de professeur. L'article présente de plus quelques objectifs dont les administrateurs pourraient tenir compte dans ce milieu particulier.

Within the management accounting and social science literature there is much speculation about the uses of budgets and the budget-setting process, but there is little reported on budgeting attitudes of budgeting personnel within universities. While most of the work in this setting has focused on retrenchment strategies, particularly in larger universities (Belanger \& Tremblay, 1982; Hardy, 1988; Hardy, 1987; Hardy, 1984; Hardy et al., 1983), a major void exists regarding the budgetary attitudes of those responsible for budgeting within small and medium universities. This paper presents survey findings of such within four universities in Ontario.

In this study, budget attitude, the dependent measure, was related to three sets of factors: the university environment and its content, context, and process variables; the environmental outcome variables of budgetees' satisfaction and commitment levels; and the budgetees' personal outcome variables. The research model is shown in Figure 1.

As in Collins' studies (Collins et al., 1987; Collins et al., 1984; Collins, 1978), "positive budget attitude" was expressed as a positive motivation, measured by the extent to which an individual desires to make a personal effort to achieve the budget and to induce budgetary responsiveness in subordinates. "Negative budget attitude" was expressed as a negative motivation, measured by the extent to which a person withholds his or her support from the budget, attempts to induce slack in the budget, or inputs erroneous or incompatible data into the budgetary system.

Considering that universities in North America have recently had to deal with reduced funding, Ontario was selected for study because of its relatively rigid budgetary environment. Within the last decade, the provincial government has consistently provided less than the budget recommended by the intermediary body (Hardy, 1988). 
Budgeting Attitudes in Smaller Universities: A Function of the

11 Environment, Environmental Outcomes, and Personal Outcomes

Figure 1

Relationship of Independent Variables to Budget Attitudes

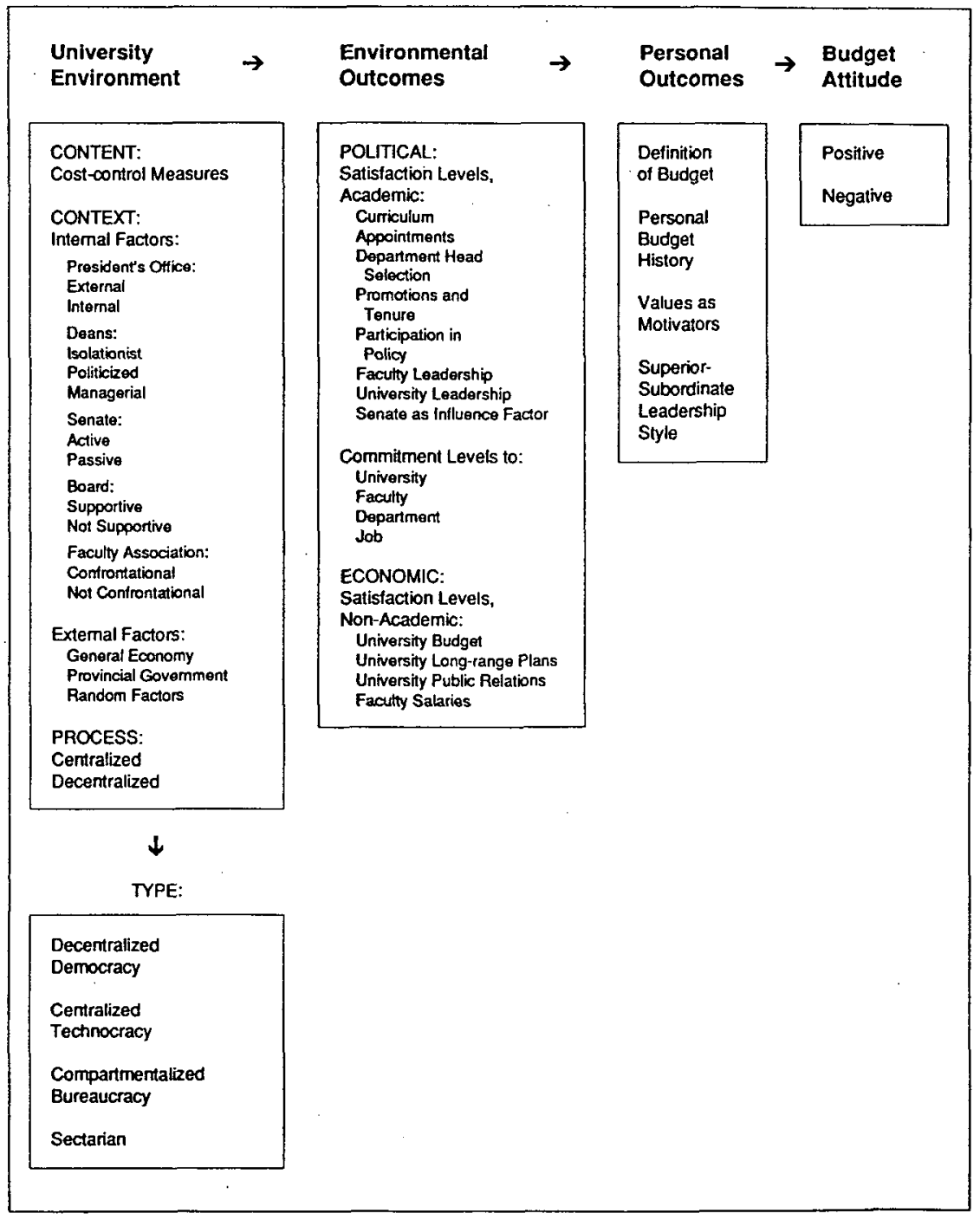

Researchers (Zammuto \& Cameron, 1985; Parker \& Zammuto, 1986) have argued that in times of cutbacks and fiscal restraint, external factors such as the state of the general economy, the mandates of the provincial governments, and other more randomly-occurring events (such as strikes) need to be differentiated for large, generalist universities and smaller, more specialist ones. Smaller educational institutions are sensitized to environmental changes. While tough 
external factors may cause larger institutions to shut departments or reduce student admissions to survive, smaller universities are typically forced to change their specialist orientations (Hardy et al., 1983; Hardy, 1984). For this reason, this study focused on the budget attitudes within incumbents of small and medium universities.

\section{THE UNIVERSITY AND ITS CONTENT, CONTEXT, AND PROCESS FACTORS}

Pettigrew (1984) maintains that in order to understand how organizations deal with budgetary restrictions, three components of strategy-making must be considered: content, context, and process. "Content" refers to what should be cut or restricted, "process" refers to how cutbacks or restrictions are to be carried out, and "context" refers to how the size, diversity, formal governance mechanisms, and culture influence the cutback or restriction process (Hardy, 1987).

In universities, the content of cutbacks or restrictions is much more limited than it is in industry. Because of tenure and collective agreements with faculty associations, lay-offs, department closures, and overly-restrictive departmental budgets are unwelcome. Regarding process, university presidents cannot impose directives on the organization without consulting with other groups in this decentralized, professional bureaucracy (Mintzberg, 1979; Hardy, 1988). Finally, given that different universities have variations in size, governance, and culture, what may be an acceptable strategy in one institution may be totally unacceptable or inappropriate in another (Blau, 1973).

Hardy (1988) suggests that four configurations representing different combinations of content, context, and process factors are common in larger universities in particular: (i) decentralized democracies, (ii) centralized technocracies, (iii) compartmentalized bureaucracies, and (iv) sectarian universities. [The reader is referred to this paper for definitions of the types.]

Considering these four configurations, the process in universities can generally be referred to as centralized (whereby others in the organization perceive that the centralized administration is guilty of "differential" resource allocation policies), or as decentralized (whereby others in the organization perceive that the decentralized administration of the budgeting process is fair and equitable, even at the departmental level; Hardy, 1987; Hardy et al., 1983).

\section{ENVIRONMENTAL OUTCOMES RELATED TO THE BUDGETEES' SATISFACTION AND COMMITMENT LEVELS}

Universities are non-profit organizations, constantly under pressure to be fiscally efficient yet politically effective in recruiting and retaining a productive, talented professoriate (Alsup et al., 1988; Hardy, 1987; Pearson, 1986). When successful, such universities boast a motivated, satisfied, and committed faculty. Thus, successful budgeting within universities implies both economic and political astuteness. The former relates to efficiency and effective resource allocation, while the latter refers to the ability to reduce conflict between competing political 
factions in order to optimize employee satisfaction and commitment levels - to the university, the faculty, the department, and the job (Hardy, 1987; Warmsley \& Zald, 1973).

While the literature seems to suggest that decentralized institutional environments allow for greater participation in the budget-setting process and thus increase the likelihood of higher levels of satisfaction and commitment for professionals, there are discrepancies in conclusions between theoretical and empirical work. While some evidence suggests that increased budgetary participation creates a more satisfied work force (Kennis, 1979; Otley, 1977), other evidence (Stedry, 1960) suggests that participation does not produce as good a performance as an "optimal" imposed budget. Other factors such as personality type and organizational size are also important (Lyne, 1988; Searfoss \& Monczha, 1973). When the employee is already over-loaded with work, a reasonable imposed budget may be more palatable and conducive to higher satisfaction levels than actual participation in the budget-setting process.

\section{THE BUDGETEES' PERSONAL OUTCOMES AND BUDGET ATTITUDE}

Role senders (Collins et al., 1984), leadership styles (Collins et al., 1984; Collins et al., 1987), and role stress (Collins et al., 1984; Clancy, 1978) reportedly affect budget attitudes. A positive attitude seems to be evoked when the budget is perceived to be a motivational rather than a punitive tool; that is, when a budget is perceived to be a target or goal to be aimed for (Lyne, 1988; Taylor, 1947; Stedry, 1960; Hofstede, 1968; Tosi, 1975; Ronen \& Livingstone, 1975).

When the effect of performance evaluation on budget attitude is considered, findings are inconsistent. While some studies have suggested that the heavy use of budget variances in performance evaluation is associated with positive budget attitudes (Collins et al., 1984), others have reported dysfunctional attitudes and behaviour resulting from such intense pressure (Argyris, 1952; Bruns \& Waterhouse, 1975; Otley, 1978; Hirst, 1983; Brownell, 1982). Schiff \& Lewin (1970) concluded that for most organizations, positive motivation can be maintained as long as the pressure to meet the budget is kept at a moderate level during the performance evaluation stage.

For the professoriate, in particular, their complex "role" is significant in defining the relevance of budgeting. The productivity of faculty is reportedly influenced by the availability of resources for fulfilling their roles in teaching, research, and service (Alsup et al., 1988; Schell \& Loeb, 1986). Given the scarce resource of time for performing these functions, the professoriate appear to prefer to make their time spent teaching, for example, to count twice; that is, teaching must furnish material for research or otherwise be a part of the research process (Summers, 1972; Schell \& Loeb, 1986). Other matters perceived to be less relevant to their self-actualization are delegated elsewhere. Faculty appear to be agreeable to having budget directors and budget committees to take care of budgetary matters, the Senate to accommodate academic matters (Hardy, 1988; Weick, 1976), and unions to deal with the economic aspects of the work situation 
(Schell \& Loeb, 1986; Gomez-Mejia \& Balkin, 1984; Ponak \& Thompson, 1984; Feuille \& Blandin, 1974; Bigoness, 1978).

\section{HYPOTHESES}

Considering the literature and the predictors outlined in Figure 1, the following hypotheses were made:

1. Small and medium universities would be characterized as a decentralized democracy by administrators and faculty members responsible for budgeting.

2. For the respondents cited above, a positive budget attitude would be prevalent.

3. Given reported norms of academic satisfaction level, economic satisfaction level, and commitment level for administrators and faculty responsible for budgeting in larger universities, similar patterns would exist for counterparts in the small and medium university system. More specifically, the patterns in the small and medium universities would more closely resemble the democratic larger systems than the technocratic larger systems.

4. Given reported perceptions of administrators and faculty responsible for budgeting in larger universities, the counterparts in the small and medium university system would similarly perceive that the provincial government and the general economy are more responsible for the current budgeting constraints in universities than are other internal university factors.

5. Given reported findings about faculty in general, the administrators and faculty responsible for budgeting in small and medium universities would have similar traits; namely, that:

- the budget would be perceived as a measure of university administrators' competence rather than as a personally punitive or corrective performance evaluation measure.

- the personal budget histories of those responsible for budgeting within small and medium universities would reflect fiscally responsible types.

- the value system of the aforementioned respondents would reflect the need to embellish one's ego, primarily through lasting accomplishments like research and publications rather than through other means.

- the superior-subordinate relationship preferred by the respondents would be consultative and not personally punitive.

6. Given the scarce resource of time within the small and medium university setting, budget attitude of the respondents would likely be correlated with budgetees' perceptions of the effectiveness of others responsible for budgeting (e.g., budget committees, budget directors, deans, department chairs) and with economic satisfaction. The correlation between budget attitude and the remaining personal outcome variables would likely be less significant.

\section{Subjects}

\section{METHOD}

A 144-item questionnaire was sent to individuals responsible for budgeting in small and medium universities (classified by size of student population) in 
Ontario, Canada. The following four universities agreed to participate, provided that the results had as the unit of analysis the budgetee rather than the university: Trent University, University of Guelph, Lakehead University, and University of Windsor.

\section{Procedure}

Questionnaires were sent to 280 faculty and administrators at these universities in November, 1988. This number represents the census of those listed in the 1987-88 Directory of Academic and Administrative Officers at Canadian Universities produced by the Association of Universities and Colleges of Canada. For the initial mailout, $187(67 \%)$ were classified as "academics" by background (Presidents, Vice-presidents Academic, Deans, School or Department Directors, Librarians, and Faculty). The remaining 93 (33\%) were classified as "administrators" by background (Chief Budget Officers, Vice-Presidents of Finance, and so on).

Approximately one week after the initial mailout, reminder cards were sent to all 280 potential respondents. By processing time, 143 questionnaires were returned, yielding a corrected response rate of $51 \%$.

For this study sample, $87 \%$ of the respondents were male, and $13 \%$ were female. The average age of respondents was 48 years. The breakdown of the sample according to current position was as follows: academic administrator, chairman: $34 \%$; academic administrator, dean: $14.5 \%$; budget committee member: $1.4 \%$; service department, director: $17.4 \%$; service department, manager or department head: $15.9 \%$; chief budget officer: $2.2 \%$; other: $14.5 \%$. The sample results revealed good representation across the specialties involved with the budgeting process. Because no data were collected on institutional affiliation, a breakdown on this variable was not possible.

\section{Questionnaire}

The 16-page questionnaire consisted of nine sections. Part I, consisting of nine possible definitions of budgeting, was developed along the lines suggested by Arnold (1981). Part II, designed to identify respondents' understanding of their university's budget practices and to ascertain the university environment typing, was developed along the work of Arnold (1981). Part III consisted of two sections: the first delineated the kinds of control measures associated with the university's budget practices (based on Merchant's work, 1985), whereas the second dealt with the perceived superior-subordinate leadership style (Collins et al., 1984). Part IV, the dependent measure part, consisted of nine budget attitude items developed by Collins (1978) and used repeatedly (Collins et al., 1984; Collins et al., 1987). Given that no reliability measure for this nine-item index has been reported, a Cronbach alpha reliability coefficient was computed for all nine items using this study's data. The results yielded a reliability coefficient of only 0.47 , which is inadequate by social science standards. Two items were found to lower the overall index reliability: "I often exceed my approved budget objectives" and "I frequently feel a personal sense of failure when budget objectives are not met." After these 
two items were deleted from this index, the Cronbach alpha reliability coefficient was improved to 0.61 . This more reliable 7 -item budget attitude index was used for the statistical analyses. Part V, detailing the impact of budgetary outcomes on performance assessment, was based on the work of Collins (1978; Collins et al., 1984; Collins et al., 1987). Part VI dealt with the political and economic environmental outcome variables in Figure 1. The items were derived from Hardy's work (1987). Part VII, based on the work of Rokeach (1973), asked the respondents to rank order from most important to least important 18 instrumental (desirable modes of conduct) and 18 terminal (desirable end-states of existence) values. Part VIII, developed by the researchers, dealt with how the respondent handles his or her personal finances. Items asked such facets as: if the respondent manages his/her family finances, the degree to which he/she is involved in the management of household income, whether or not he/she regularly puts funds aside in anticipation of future expenses, whether he/she ordinarily borrows funds for purchases which he/she cannot afford, and so on. Part IX included the background items typically found in surveys of this type.

\section{RESULTS}

\section{The Environment in Small and Medium Universities}

When presented with seven statements which assessed the respondents' views about the way the university allocates resources among faculties and departments (see Table 1), the administrators and faculty alike agreed that resource allocation decisions are based on what objectivity seems best for the university overall, and that the university has a standard set of procedures it uses to make resource allocation decisions. Beyond this overall objective of what is best for the university is best for the majority, the respondents seem to feel that the "share of the pie" is then sliced according to political factions. Given a choice between items suggesting an autocracy or that of a democracy, the findings suggest that resource allocation is more likely to be a matter for group discussion and concensus rather than one that is decided autocratically. The majority, 70\%, confirmed that budget committees exist in their institutions, and were perceived to be, on the average, moderately effective. When asked how important various groups or individuals were in influencing decision outcomes in general at their universities, the rankings from most important to least important were as follows: central administration, deans, department heads, professors. This pattern appears to be reflective of a decentralized system that is perceived to be fair rather than differential. Such a finding supports hypothesis 1 .

Regarding the budget process, the respondents agreed that decisions in the university's budget process are made at high levels in the chain of command. The respondents said that not only are representatives of all groups in the university included in the budget process, but that they felt that budget responsibilities are controlled through specific procedures, not arbitrarily defined ones. When given a 
Budgeting Attitudes in Smaller Universities: A Function of the

Views About How the University Allocates Resources Beween Faculties/Department: How would you respond to each item below, on a 1 through 5 scale?

1 - totally disagree

5 - totally agree

\begin{tabular}{|c|c|c|c|}
\hline \multirow[b]{2}{*}{ Item } & & \multicolumn{2}{|c|}{$\underline{\mathbf{N}}=135$} \\
\hline & & M & SD \\
\hline- & & - & - \\
\hline & $\begin{array}{l}\text { The university has a standard set of } \\
\text { procedures it uses to make resource } \\
\text { allocation decisions. }\end{array}$ & 2.91 & 1.10 \\
\hline 2. & $\begin{array}{l}\text { One individual makes all resource } \\
\text { allocation decisions of any consequence. }\end{array}$ & 2.44 & 1.21 \\
\hline 3. & $\begin{array}{l}\text { No particular pattern characterizes the } \\
\text { process by which resource allocation } \\
\text { decisions are made. }\end{array}$ & 2.22 & 1.05 \\
\hline 4. & $\begin{array}{l}\text { Resource allocation decisions are } \\
\text { political, based on the relative power } \\
\text { of those involved. }\end{array}$ & 2.70 & 1.11 \\
\hline 5. & $\begin{array}{l}\text { Resource allocation is decided } \\
\text { autocratically. }\end{array}$ & 2.50 & 1.10 \\
\hline 6. & $\begin{array}{l}\text { Resource allocation is a matter for } \\
\text { group discussion and concensus. }\end{array}$ & 2.66 & 0.90 \\
\hline 7. & $\begin{array}{l}\text { Resource allocation decisions are based } \\
\text { on what objectively seems best for the } \\
\text { university overall. }\end{array}$ & 3.23 & 0.87 \\
\hline
\end{tabular}

choice between headcount controls, financial controls limiting the expenditure level, procedural restriction controls, or "directive" controls as the predominant measure for limiting discretionary expenditures, the majority perceived financial controls to be the most significant in their institutions. When asked to what extent faculty/department budget over-expenditures are forgiven, the majority of respondents suggested a system which was moderately forgiving. These findings also support hypothesis 1 .

\section{Budget Attitudes}

Responses were averaged to yield a measure of overall budget attitude for each respondent; the higher the score, the more positive the budget attitude. For this particular study group, the mean overall budget attitude index score on a 7-point scale was 5.05 ( $S D: 0.77, N=129$ ). Such findings support hypothesis 2 .

To assess the relative impact of the background variables on budget attitude, one-way analyses of variance with sex, age, tenure in position, and so on, were completed. Because not one of the biographical variables appeared to have a significant association with budget attitude, the multivariate statistical analyses were based on the pooled sample of faculty and administrators. 
Table 2

Views About Some Environmental outcomes: Large, Small, and Medium Universities How would you respond to each item below, on a 1 through 5 scale?

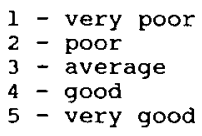

\begin{tabular}{|c|c|c|c|c|c|c|}
\hline \multirow{2}{*}{ Item } & \multirow{2}{*}{\multicolumn{3}{|c|}{$\begin{array}{l}\text { Technocratic } \frac{M}{1} \\
\text { Large University }\end{array}$}} & \multirow{3}{*}{$\begin{array}{l}\text { Democratic } \frac{\mathrm{M}}{\text { Large University }} \\
3.0\end{array}$} & \multirow{2}{*}{\multicolumn{2}{|c|}{$\begin{array}{l}\underline{\mathrm{N}}=136 \\
\text { Democratic } \mathrm{M} \\
\text { Small-Medium } \\
\text { University }\end{array}$}} \\
\hline & & & & & & \\
\hline 1. & $\begin{array}{l}\text { Your present } \\
\text { annual salary. }\end{array}$ & & 3.7 & & 3.4 & $(0.80)$ \\
\hline 2. & $\begin{array}{l}\text { The extent of } \\
\text { faculty } \\
\text { participation i } \\
\text { determination } \\
\text { academic polici } \\
\text { and procedures. }\end{array}$ & $\begin{array}{l}\text { in the } \\
\text { of } \\
\text { ies }\end{array}$ & 2.8 & 3.4 & 3.5 & $(0.87)$ \\
\hline 3. & $\begin{array}{l}\text { Your general } \\
\text { confidence in } \\
\text { leadership of } \\
\text { faculty. }\end{array}$ & $\begin{array}{l}\text { the } \\
\text { your }\end{array}$ & 2.8 & 3.5 & 3.6 & $(0.89)$ \\
\hline I & $\begin{array}{l}\text { Your general } \\
\text { confidence in } \\
\text { leadership of } \\
\text { university. }\end{array}$ & $\begin{array}{l}\text { the } \\
\text { the }\end{array}$ & 2.7 & 3.4 & 3.7 & $(0.88)$ \\
\hline 5. 3 & $\begin{array}{l}\text { The value of } \\
\text { as an avenue } \mathrm{fo} \\
\text { faculty influen }\end{array}$ & $\begin{array}{l}\text { enate } \\
\text { or } \\
\text { ence. }\end{array}$ & 2.6 & 3.4 & 3.0 & $(0.98)$ \\
\hline & Hardy, & 1987 & p. 77 & & & \\
\hline
\end{tabular}

\section{The Environmental Outcomes in Small and Medium Universities}

Data comparing the mean scores of items relating to environmental outcome variables of large and small-to-medium universities are presented in Tables 2, 3, and 4 . For each table, the first column presents findings for a technocratic large university, the second column presents such for a democratic large university, and the third column presents this study's findings for small-to-medium universities. Data in the first two columns were obtained from Hardy (1987).

Because no standard deviation scores were cited for the larger university systems, only patterns of similarities and contrasts can be discussed here. The data in Tables 2 through 4 reveal that the mean scores for the items relating to environmental outcomes are much closer to the scores previously published for the democratic large university system than for the technocratic large university system. Such findings support hypothesis 3 .

For data in these tables, if one were to assume that a mean score value of 3 is indicative of general discontent regarding the facet in question, the findings from 
Table 3

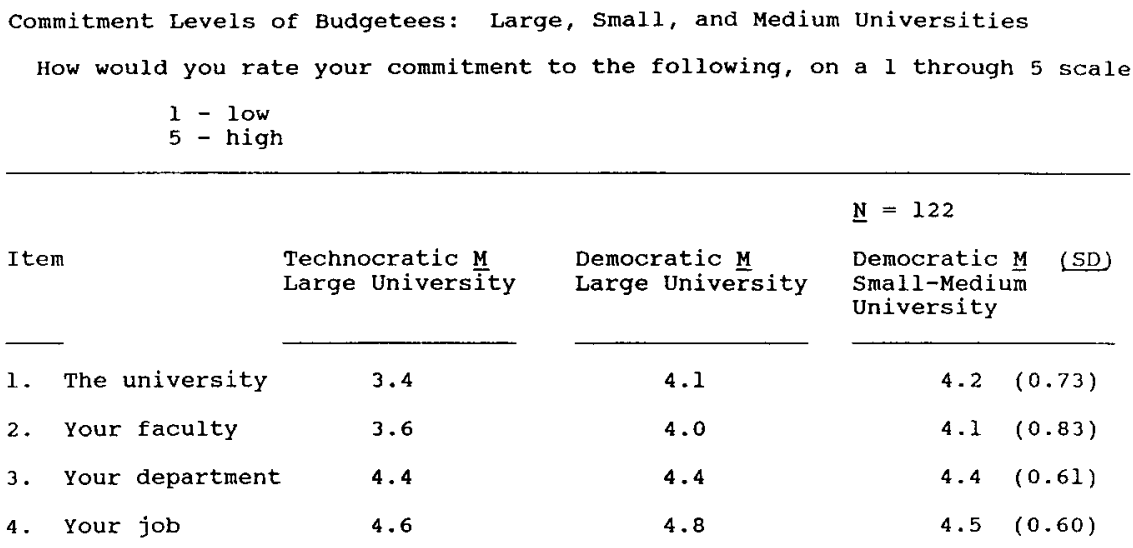

Source: Hardy, 1987, p. 78

this study would suggest that in general faculty in technocratic large universities are more likely to be discontent with a number of outcomes. The data reveal that for the technocratic larger university, $60 \%$ of the mean scores were below 3 , while only $24 \%$ of the mean scores were below 3 for the large, small, and medium democratic university systems. For the small and medium universities, the major areas of discontent were with faculty budgets, university budgets, long-range university plans, and external/public relations. In short, hypothesis 3 was supported.

\section{Factors Responsible for Current Budgetary Constraints}

When asked about the factors responsible for current budgetary constraints in small and medium universities, the respondents seemed to agree that the government is the most responsible, followed by the general economy, the university administration, the faculty, and other factors. Such findings support hypothesis 4 .

\section{Personal Outcome Factors and Budget Attitudes in Small and Medium Universities}

(i) Definition of budget. Of nine definitions offered, the definition receiving the highest mean score was: "A budget is a visual indication that the university is being run properly." Such a finding is consistent with hypothesis 5.

(ii) Personal budget history of respondents. The majority, $88 \%$ of the respondents, attest to managing their personal and/or family finances. For the remaining $12 \%$ who do not, the spouse is the most likely individual to do so ( $83 \%$ of the $12 \%$ suggested such). The respondents also reported: putting funds aside in anticipation of future expenses, not borrowing funds for purchases which they 


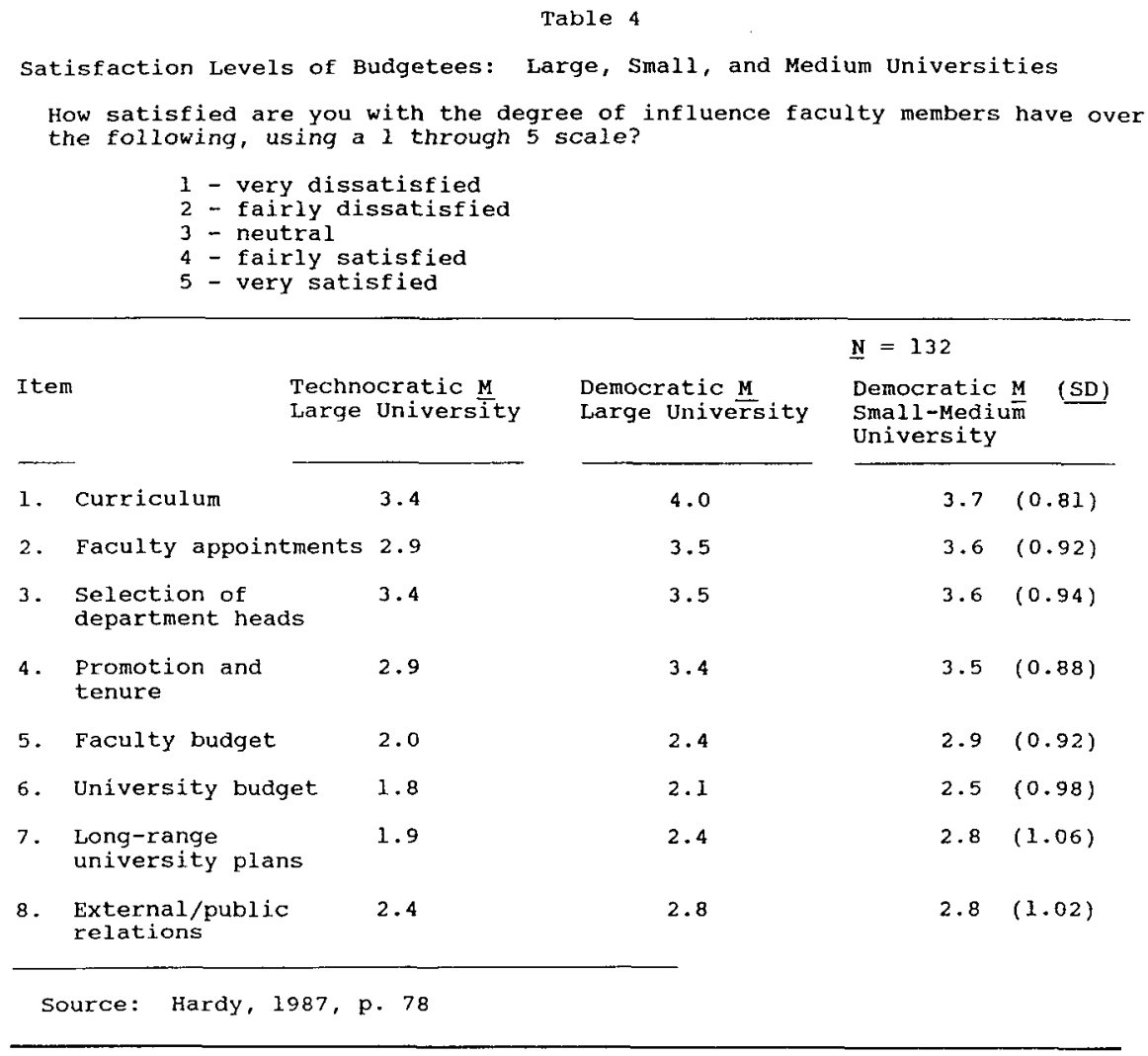

cannot afford on a current basis, rarely having bank accounts go into overdraft, and not having had wages garnisheed. Such a pattern supports hypothesis 5 .

(iii) Value systems. The values receiving the lowest mean ranks on the Rokeach Human Values Inventory (1973), whereby the lower the score the higher the importance level were: the instrumental values of honesty and capability, and the terminal values of a sense of accomplishment and lasting contribution and a need for self-respect. The least needed instrumental value was obedience, while the least important terminal value was salvation. Such results support hypothesis 5 .

(iv) Superior-subordinate leadership styles. When budgetees rated four factors on the actual influence each has on forming their budget attitudes, the immediate superior was perceived to be the most influential in determining respondents' budget attitudes.

Five items were presented that asked about the impact of budgetary outcomes on performance assessment of the budgetees. The mean scores for the items are given in Table 5, along with the mean item scores for 128 budgetees in large industry firms. The results indicate that while consultation with the immediate superior appears to exist in universities, accountability by budgetees for budgetary outcomes appears to play a minimal role in performance assessment in the small and medium university setting, consistent with hypothesis 5 . 
Table 5 .

Factors Affecting Impact of Budgetary Outcomes on Performance Assessment: Large Firm Budgetees and Small and Medium University Budgetees

Regarding your immediate superior, indicate your degree of agreement or disagreement, using a 1 through 6 scale.

1 - totally disagree

6 - totally agree

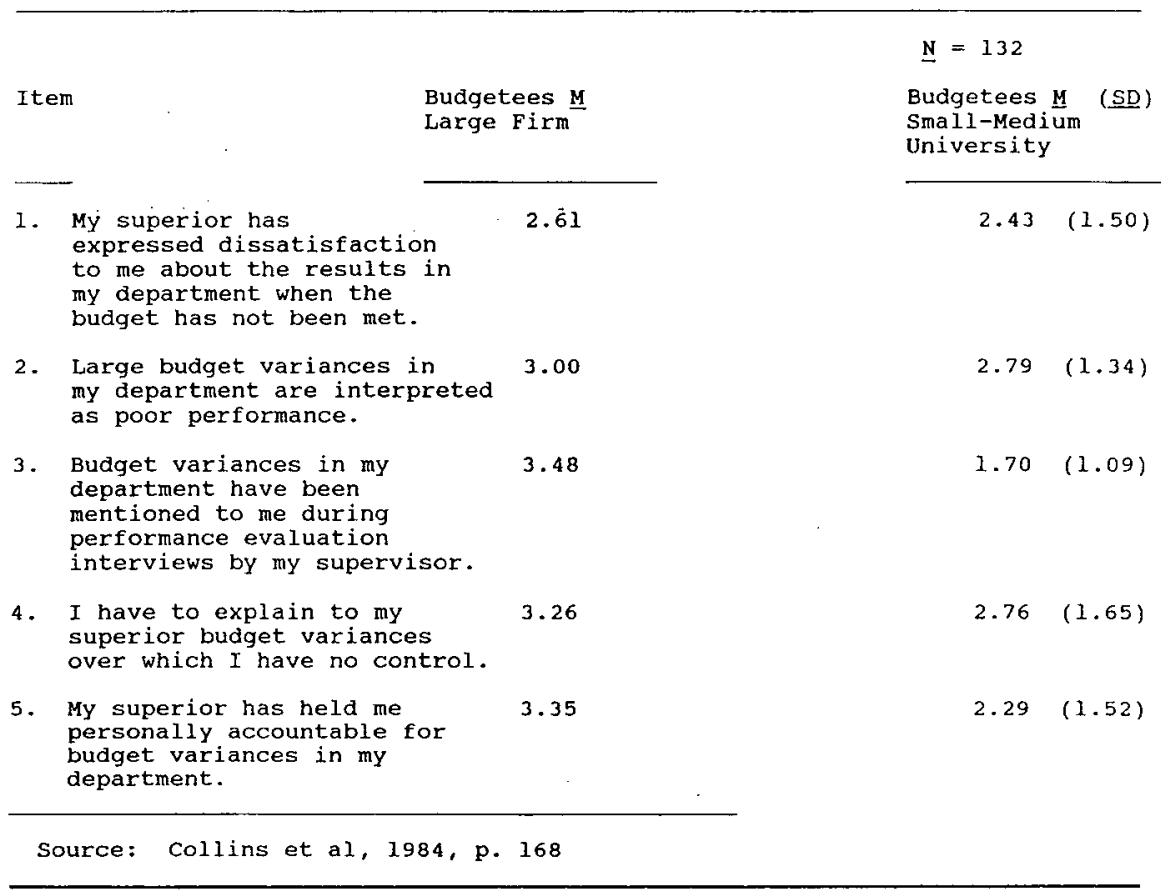

\section{Summary and Review of Figure 1}

A Pearson correlation matrix was computed which produced the coefficients between budget attitude index and each metric predictor item in Figure 1. To save space, the results are not presented here but are available from the authors. In total, 45 variables were found to have a coefficient significant at $p<0.05$. To develop a "short list" of the most influential predictors, a forward-inclusion, multiple regression analysis was completed with budget attitude as the dependent variable and with these 45 predictors. The results are presented in Table 6 . As suggested in hypothesis 6 , effective use of time and energy appears to underlie the results of Table 6 . The predictor most highly and positively correlated with budget attitude was the budgetees' satisfaction with the degree to which faculty members within small-medium settings are permitted to influence faculty and departmental budgets. The next two influential predictors were the degree to which faculty members could influence the public image of the university and the degree of effectiveness of the budget committees. It seems clear that, as noted in hypothesis 
Table 6

Summary of Forward Inclusion Multiple Linear Regression:

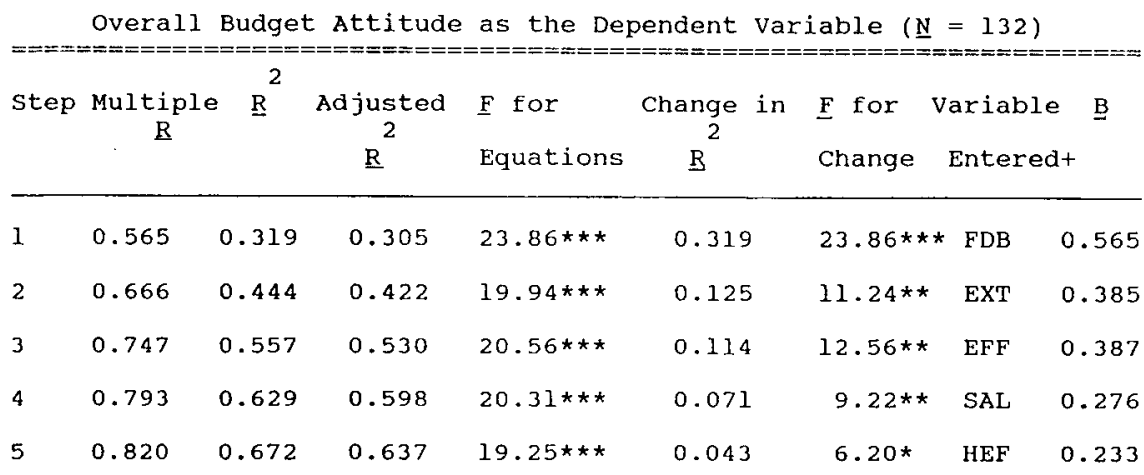

1. FDB: Satisfaction with degree of influence faculty have in determining faculty/department budgets.

2. EXT: Satisfaction with degree of influence faculty have in determining external/public relations.

3. EFF: Perceived degree of effectiveness of university budget committee.

4. SAL: Satisfaction with present salary.

5. HEF: Perceived system's effectiveness of allocating budget amounts for expenditures.

$\star \star \star p<0.000$

$\star * \quad \mathrm{p}<0.001$

$\star \quad p<0.05$

6 , faculty perceive that they make the best use of their time by getting involved in the "local" budget politics of the faculty or department rather than getting involved in setting budget policy for other units or for the university as a whole. Such a job is better left to an effective budget committee.

Also, as noted in the Gomez-Mejia \& Balkin, 1974, study, when faculty think of budgets, they think of adequate salaries; the findings here support hypothesis 6 . Consistent with the respondents' perceptions of a budget as a means of assessing the effectiveness of others' responsible for budgeting, these data suggest that when the system is perceived to be effective in allocating budget amounts for expenditures, a positive attitude is likely to result.

\section{DISCUSSION}

For this Ontario sample of four small and medium universities, the findings suggest a perceived positive university environment, characterized by high faculty and administration budgetees' satisfaction, commitment, and budget attitude levels. It should be emphasized that significant differences were not found in the dependent measures when "administrative" and "academic" background 
budgetees were compared. Dismayed that scarce provincial funding and a tight economy have constrained the university budgetary process, the pooled sample of budgetees in small and medium universities believed that the less-than-ideal situation could be made bearable where environments supporting fair budget control initiatives existed.

Some shortcomings were noted, however. Overall, the budgetee respondents felt a lack of attachment to the budget system in their small-medium universities. This finding was noted in the perception by definition that a budget is primarily a measure of university administrators' competence. It was noted as well in the demonstrated interest in "local" or departmental budget actions as compared to the overall university budget activities. It was manifested also in the lack of personal accountability for variances that could or did occur at the local level. It was noted in a feeling of dismay over the universities' less-than-perfect external images and over the universities' less-than-perfect internal financial rewards.

The pattern described above has some inherent "mixed messages" built into it regarding predictors of positive budget attitudes for those responsible for budgeting. On the one hand, there seems to be a cry by faculty, in particular, for optimizing their personal values of self-accomplishment and self-embellishment by allowing them to concentrate their time and energies on teaching and research. There is the concurrent suggestion that budgets are better left to fair and effective administrators, budget committees, and budget directors. On the other hand, there seems to be a more subtle message that the faculty in particular want to get involved in budget-setting at the "local" level, but the immediate superior seems not to be taking the initiative to get the faculty involved or to hold them accountable for variances that do occur at the local level.

Before resolving these apparent contradictions, let's focus for the moment on the apparent predictors of positive budget attitudes that seem to be shared by administrators and faculty alike. First, respondents were not critical of overall allocations, pointing to the negative external pressures of provincial funding and a tight economy as causes of the constraints. Recognizing that the small-medium university is primarily a decentralized democracy, the budgetees seemed to suggest that with their limited time, budget decisions made at the local level were priorities for them; budget decisions made at broader levels were priorities for "fair" budget committees and budget administrators.

Along this line, the roles of administrators, budget committees, and budget directors were at the focus for maintaining satisfaction levels for the community at large. Adequate consultation by the committees and directors to budgetees at the local level was a must. It is at this link-attitudes and superior-subordinate leadership styles - that the weakness in the chain becomes apparent. While there appears to be some consultation by superiors with subordinates at the local level regarding budgetary matters, accountability for budget variances at even the local level appear to be down-played by the superiors in this decentralized system. And where there is no accountability, there appears to be a lack of commitment to the budgetary process - at even the local level. The blame, then, for things that go 
wrong with budgets is displaced to responsible others within the system particularly the administrators. What is interesting, as noted above, is that our findings seem to suggest that budgetees at all levels of the small-medium universities would be prepared to be more behaviourally accountable for budget variances if superiors were more assertive in suggesting such. The performance assessment arena appears to be a distinct possibility for making such assertions. If such accountability for budget variances were to be put in place at the local level, clear-cut criteria should be established and transmitted to those responsible for budgeting. While this study did not ascertain which criteria could be useful in this regard, future research could address the question for this small-medium university setting.

As a result of this study's findings, we feel that two pointers are worthy of consideration by administrators, budget committees, and budget directors in laying a framework for positive budgetary control. First, even in decentralized democracies, when resources are accepted by the majority as being scarce, the budgetees appear to prefer to make at least rudimentary budgetary decisions at the local level rather than to make no decisions at all or to have little input in the budget-setting process. Further, while they do not desire to spend lots of energy in making time-consuming judgements on priorities and broad-based decisions, they desire some accountability, given well-defined budget parameters and universitywide objectives. While they do not seek the responsibility for inherent fiscal judgement calls, they expect that the budget committees and directors should be able to define a universal budget mandate to which all groups could steer their limited energies. The development of such university-wide fiscal objectives appears to be another weak link in the chain. Besides a lack of direction from superiors on the budget variance accountability issue, the respondents perceive a real need to develop universal targets that could pull the administrative and academic community together. At the present time, such targets appear to be lacking.

Second, while the mean budget attitude appears to be high in the small-medium university setting, the results from this study indicate that the system could be improved. Perhaps linked to the above point, the findings seem to suggest that both administrative and faculty budgetees are losing sight of the overall university mandate. Without true involvement at even the local or departmental level, budgetees seem to be missing a psychological bond or emotional commitment to broader university goals and objectives. Perhaps the dissatisfaction expressed by the majority around the issue of external relations and long-range university plans was an overt expression of the need to be more personally involved in the budget process. In this study, while behavioural measures for budgetees' improving the external image were not measured directly, the findings suggest that such an area of study deserves further research.

Finally, the results from this study indicate that the personal budget histories and values of budgetees appear to contribute little to developing a positive budget attitude in small and medium universities. However, clear-cut targets, a 
consultative superior-subordinate leadership style, and accountability by budgetees at at least the local level appeared to be crucial. Such an equation suggests that budgetees are prepared to work hard at the individual level as long as a fair allocation process with competent budgeting committees and budgeting personnel exist, and as long as individuals can take home in their pockets their "fair share" of the financial pie.

\section{REFERENCES}

Alsup, R.G., Holland, M.L. \& Jacobs, F.A. (1988). The Perceived Availability of Resources Which Contribute to Accounting Faculty Productivity. Journal of Accounting Education, 6, 261-277.

Argyris, C. (1952). The Impact of Budgets on People. New York: The Controllership Foundation.

Arnold, L. (1981). How Do We Cut the Cake, A Survey of Resource Allocation Procedures at Selected Canadian Universities. Toronto: Survey for the Canadian Association of Business Officers.

Belanger, C. \& Tremblay, L. (1982). A Methodological Approach to Selective Cutbacks. Canadian Journal of Higher Education, 12(3), 25-36.

Bigoness, W.J. (1978). Correlates of Faculty Attitudes Toward Collective Bargaining. Journal of Applied Psychology, 63, 228-239.

Blau, P.M. (1973). The Organization of Academic Work. New York: Wiley.

Brownell, P. (1982). The Role of Accounting Data in Performance Evaluation, Budgetary Participation, and Organizational Effectiveness. Journal of Accounting Research, 20(1), 12-27.

Bruns, W.J. \& Waterhouse, J.H. (1975). Budgetary Control and Organization Structure. Journal of Accounting Research, 13(2), 177-203.

Clancy, D.K. (1978). The Management Control Problems of Responsible Accounting. Management Accounting, 60, 35-39.

Collins, F. (1978). The Interaction of Budget Characteristics and Personality Variables with Budgetary Response Attitudes. Accounting Review, 53, 324-335.

Collins, F., Seiler, R.E. \& Clancy, D.K. (1984). Budgetary Attitudes: The Effects of Role Senders, Stress and Performance Evaluation. Accounting and Business Research, 54, 163-168.

Collins, F., Munter, P. \& Finn, D.W. (1987). The Budgeting Games People Play. The Accounting Review 62(1), 29-49.

Feuille, P. \& Blandin, J. (1974). Faculty Job Satisfaction and Bargaining Sentiments: A Case Study. Academy of Management Journal, 17, 678-692.

Gomez-Mejia, L.R. \& Balkin, D.B. (1984). Faculty Satisfaction with Pay and Other Job Dimensions Under Union and Nonunion Conditions. Academy of Management Journal, 27, 591-602.

Hardy, C., Langley, A., Mintzberg, H. \& Rose, J. (1983). Strategy Formation in the University Setting. The Review of Higher Education, 6(4), 407-433.

Hardy, C. (1984). The Management of University Cutbacks: Politics, Planning and Participation. Canadian Journal of Higher Education, 14(1), 79-89.

Hardy, C. (1987). Using Content, Context and Process to Manage University Cutbacks. Canadian Journal of Higher Education, 17(1), 65-82.

Hardy, C. (1988). Managing the Interest Groups in University Structures. Academy of Management Best Papers Proceedings, Frank Hoy (Ed.). Annaheim, California, pp. 362-366.

Hirst, M.K. (1983). Reliance on Accounting Performance Measures, Task Uncertainty and Dysfunctional Behaviour: Some Extensions. Journal of Accounting Research, 21, 596-605.

Hofstede, G.H. (1979). The Game of Budgetary Control. England: Tavistock, 1968.

Kennis, I. (1979). Effects of Budgetary Goal Characteristics on Managerial Attitudes and Performance. Accounting Review, 54(4), 707-721.

Lyne, S.R. (1988). The Role of the Budget in Medium and Large UK Companies and the Relationship with Budget Pressure and Participation. Accounting and Business Research, 18(71), 195-212. 
Merchant, K. (1981). The Design of Corporate Budgeting Systems: Influences on Managerial Behavior and Performance. Accounting Review, 56, 813-829.

Mintzberg, H. (1979). The Structuring of Organizations. Englewood Cliffs, NJ: Prentice Hall.

Otley, D.T. (1977). Behavioural Aspects of Budgeting. Accounting Digest, 49.

Otley, D.T. (1978). Budget Use and Managerial Performance. Journal of Accounting Research, 16, $122-149$.

Parker, L.D. \& Zammuto, R. (1986). Institutional Responses to Enrollment Decline: The Role of Perceptions. Paper presented at the Annual Meeting of the Association for the Study of Higher Education, San Antonio, Texas.

Pearson, M. (1986). Managing for Excellence or Walk the Jarratt Way. Paper presented at the 8th European Forum of the Association of Institutional Research, Loughborough, England.

Pettigrew, A.M. (1984). Culture and Politics in Strategic Decision Making and Change. Paper presented at the Symposium on Strategic Decision Making in Complex Organizations. Columbia University, New York.

Ponak, A. \& Thompson, M. (1984). Faculty Collective Bargaining: The Voice of Experience. Relations Industrielles, 39, 449-463.

Rokeach, M. (1973). The Nature of Human Values. New York: The Free Press, pp. 359-361.

Ronen, J. \& Livingstone, J.L. (1975). An Expectancy Theory Approach to the Motivational Impact of Budgets. Accounting Review, 50(4), 671-685.

Schell, B.H. \& Loeb, A.S. (1986). An Investigation of General Happiness Level, Collective Bargaining Attitudes, Job Satisfaction, and University and Union Commitment of Faculty Members in Canada. Journal of Social Behavior and Personality, 1(4), 537-556.

Schiff, M. \& Lewin, A.Y. (1970). The Impact of People on Budgets. Accounting Review, 45, 259-268.

Searfoss, R.G. \& Monczha, R.M. (1973). Perceived Participation in the Budget Process and Motivation to Achieve the Budget. Academy of Management Journal, 16, 541-553.

Stedry, A.C. (1960). Budget Controls and Cost Behavior. Englewood-Cliffs, NJ: Prentice-Hall.

Summers, E.L. (1972). An Inquiry into the Conditions Favoring Research by Members of an Accounting Faculty. In R.R. Sterling (Ed.), Research Methodology in Accounting, pp. 137-151. Houston: Scholars Book Co.

Taylor, F.W. (1947). Scientific Management. New York: Harper.

Tosi, H. (1975). The Human Effects of Managerial Budgeting Systems. In J.L. Livingstone (Ed.), Management Accounting: The Behavioral Foundations. New York: Grid.

Warmsley, G.L. \& Zald, M.N. (1973). The Political Economy of Public Organizations. Public Administration Review, 33, 62-73.

Weick, K.E. (1976). Organisations as Loosely Coupled Systems. Administrative Science Quarterly, 21, 1-19.

Zammuto, R.F. \& Cameron, K.S. (1985). Environmental Decline and Organizational Response. Research in Organizational Behavior, 7, 223-262. 